\title{
A MODEL OF SYNOVIAL FLUID LUBRICANT COMPOSITION IN NORMAL AND INJURED JOINTS
}

\author{
ME Blewis ${ }^{1}$, GE Nugent-Derfus ${ }^{1}$, TA Schmidt ${ }^{1}$, BL Schumacher $^{1}$, and RL Sah ${ }^{1,2^{*}}$
}

Departments of ${ }^{1}$ Bioengineering and ${ }^{2}$ Whitaker Institute of Biomedical Engineering, University of California-San Diego, La Jolla, CA

\begin{abstract}
The synovial fluid (SF) of joints normally functions as a biological lubricant, providing low-friction and low-wear properties to articulating cartilage surfaces through the putative contributions of proteoglycan 4 (PRG4), hyaluronic acid (HA), and surface active phospholipids (SAPL). These lubricants are secreted by chondrocytes in articular cartilage and synoviocytes in synovium, and concentrated in the synovial space by the semi-permeable synovial lining. A deficiency in this lubricating system may contribute to the erosion of articulating cartilage surfaces in conditions of arthritis. A quantitative intercompartmental model was developed to predict in vivo SF lubricant concentration in the human knee joint. The model consists of a SF compartment that (a) is lined by cells of appropriate types, (b) is bound by a semi-permeable membrane, and (c) contains factors that regulate lubricant secretion. Lubricant concentration was predicted with different chemical regulators of chondrocyte and synoviocyte secretion, and also with therapeutic interventions of joint lavage and HA injection. The model predicted steady-state lubricant concentrations that were within physiologically observed ranges, and which were markedly altered with chemical regulation. The model also predicted that when starting from a zero lubricant concentration after joint lavage, PRG4 reaches steady-state concentration $\sim 10-40$ times faster than HA. Additionally, analysis of the clearance rate of HA after therapeutic injection into SF predicted that the majority of HA leaves the joint after $\sim 1-2$ days. This quantitative intercompartmental model allows integration of biophysical processes to identify both environmental factors and clinical therapies that affect SF lubricant composition in whole joints.
\end{abstract}

Keywords: synovial fluid, proteoglycan 4, hyaluronic acid, permeability, cartilage, synovium, lavage, HA injection

Address for correspondence*

Dr. Robert L Sah

Department of Bioengineering

9500 Gilman Dr., Mail Code 0412,

University of California, San Diego

La Jolla, CA 92093-0412

Telephone: (858) 534-0821

Fax: (858) 822-1614

E-mail: rsah@ucsd.edu

\section{Introduction}

The synovial fluid (SF) of natural joints normally functions as a biological lubricant as well as a biochemical pool through which nutrients and regulatory cytokines traverse. SF contains molecules that provide low-friction and low-wear properties to articulating cartilage surfaces. Molecules postulated to play a key role, alone or in combination, in lubrication are proteoglycan 4 (PRG4) (Swann et al., 1985) present in SF at a concentration of $0.05-0.35 \mathrm{mg} / \mathrm{ml}$ (Schmid et al., 2001a), hyaluronan (HA) (Ogston and Stanier, 1953) at 1-4 mg/ml (Mazzucco et al., 2004), and surface-active phospholipids (SAPL) (Schwarz and Hills, 1998) at $0.1 \mathrm{mg} / \mathrm{ml}$ (Mazzucco et al., 2004). Synoviocytes secrete PRG4 (Jay et al., 2000; Schumacher et al., 1999) and are the major source of SAPL (Dobbie et al., 1995; Hills and Crawford, 2003; Schwarz and Hills, 1996), as well as HA (Haubeck et al., 1995; Momberger et al., 2005), in SF. Other cells also secrete PRG4, including chondrocytes in the superficial layer of articular cartilage (Schmid et al., 2001b; Schumacher et al., 1994) and, to a much lesser extent, cells in the meniscus (Schumacher et al., 2005).

As a biochemical depot, SF is an ultrafiltrate of plasma that is concentrated by virtue of its filtration through the synovial membrane. The synovium is a thin lining $(\sim 50$ $\mu \mathrm{m}$ in humans) comprised of tissue macrophage A cells, fibroblast-like B cells (Athanasou and Quinn, 1991; Revell, 1989; Wilkinson et al., 1992), and fenestrated capillaries (Knight and Levick, 1984). It is backed by a thicker layer $(\sim 100 \mu \mathrm{m})$ of loose connective tissue called the subsynovium (SUB) that includes an extensive system of lymphatics for clearance of transported molecules. The cells in the synovium form a discontinuous layer separated by intercellular gaps of several microns in width (Knight and Levick, 1984; McDonald and Levick, 1988). The extracellular matrix in these gaps contains collagen types I, III, and V (Ashhurst et al., 1991; Rittig et al., 1992), hyaluronan (Worrall et al., 1991), chondroitin sulphate (Price et al., 1996; Worrall et al., 1994), biglycan and decorin proteoglycans (Coleman et al., 1998a), and fibronectin (Poli et al., 2004). The synovial matrix provides the permeable pathway through which exchange of molecules occurs (Levick, 1994), but also offers sufficient outflow resistance (Coleman et al., 1998a; Scott et al., 1998) to retain large solutes of SF within the joint cavity. Together, the appropriate reflection of secreted lubricants by the synovial membrane and the appropriate lubricant secretion by cells are necessary for development of a mechanically functional SF.

The mechanobiology of joints and SF constitutes a complex, low-friction, low-wear system that is normally in homeostasis. However, in arthritis, injury, and artificial 
joint failure, there is increased friction between the articulating surfaces and concomitant erosion of the load bearing elements (Buckwalter and Mankin, 1997). This increase in friction is associated with altered SF composition. Specifically, the SF PRG4 concentration decreases following acute injury, as does the frictionlowering property of such SF (Elsaid et al., 2005), while PRG4 concentration increases in patients undergoing arthrocentesis procedures (Schmid et al., 2001a). HA (Belcher et al., 1997) and SAPL (Rabinowitz et al., 1984) also exhibit decreased concentrations in osteoarthritis, and $\mathrm{HA}$ is also decreased with failure of artificial joints (Mazzucco et al., 2004). The mechanisms by which altered SF lubricant composition occur are unknown.

Joint injury and arthritis may additionally result in dramatic changes in the concentration of some cytokines in SF (Bertone et al., 2001; Cameron et al., 1994; Fahlgren et al., 2001; Fava et al., 1989; Moos et al., 1999; Okazaki et al., 2001; Wei and Messner, 1998). A complex milieu of regulatory cytokines exists in SF, including TGF- $\beta$, IGF1, TNF- $\alpha$, IL-1, and IL-6 (Fava et al., 1989; Kaneyama et al., 2005; Schalkwijk et al., 1989; Van ObberghenSchilling et al., 1988; Wei and Messner, 1998). The cytokines TGF- $\beta$ and IL- 1 can have significant effects on secretion of lubricants by both chondrocytes and synoviocytes. IL-1 downregulates PRG4 secretion by chondrocytes, while TGF- $\beta$ upregulates PRG4 secretion (Flannery et al., 1999; Schmidt et al., 2005). Additionally, both TGF- $\beta$ and IL-1 result in increased HA secretion by synoviocytes (Haubeck et al., 1995; Momberger et al., 2005). Thus, the changing chemical environment with injury and arthritis may have significant effects on lubricant secretion by cells, and, consequently, SF lubricant composition.

A variety of treatments have been developed to alter biologically the synovial joint environment in injury and arthritis. Some pharmaceutical agents are capable of reducing pain and inflammation (Furst, 2004; Moreland, 2004). HA injections have been purported to affect the biology of the joint in order to restore the viscosity and protective functions of the synovial fluid (Moreland, 2003; Tehranzadeh et al., 2005). Therapeutic joint lavage has been used to cleanse the joint of cartilage degradation products, proinflammatory cells, and destructive enzymes associated with arthritis (Ayral, 2005), and can be performed alone or in combination with anti-inflammatory steroids (Frias et al., 2004; Tanaka et al., 2006). These treatments have not specifically targeted restoration of lubrication in joints, and treatment effects on SF lubricant composition have not yet been examined.

The whole synovial joint, including cartilage, synovium and SF (Fig. 1), presents complexities that make it difficult to measure continuously the in vivo SF lubricant composition, and also the main determinants of dynamics in this composition. General models of fluid flow and solute transport through a matrix (reviewed in (Curry, 1984; Levick, 1987)) have been developed, and extensive analysis of the synovium structure has been performed to obtain values for functional parameters that control its transport properties (Levick, 1994; Levick and McDonald, 1989a; Levick and McDonald, 1989b; Price et al., 1996;

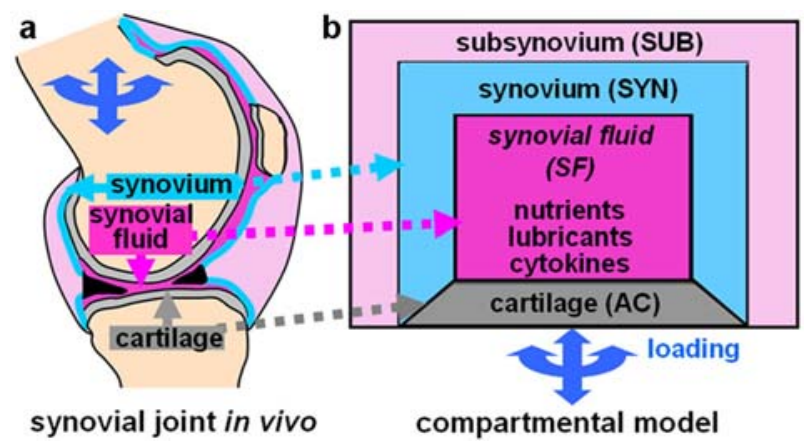

Figure 1. (a) Synovial joints are generally composed of cartilage, synovium, and SF, (b) modelled by communicating compartments in which chemical and mechanical factors regulate lubricant secretion.

Price et al., 1995; Sabaratnam et al., 2005; Scott et al., 2003). Knowledge of the structure of synovium, along with related published data, has been applied to the models of fluid and solute transport to specifically model the flow of albumin from synovial capillaries into SF and out through the synovial membrane (Levick, 1994). Additionally, the concept of combining the theory of mass balance with the data on fluid and solute transport through the synovium has been introduced as an approach for determining the concentration of a molecule in SF, such as a lubricant (Levick, 1998).

Thus, the objective of this study was to develop a mathematical model to analyze lubricant composition in SF of whole human knee joints, expanding upon the approaches taken in previous studies and utilizing relevant published functional parameters. The model was applied to determine theoretically (1) the steady-state lubricant concentration in SF under normal and altered chemical environments in the synovial joint that may occur with injury and disease, (2) the kinetics associated with attaining these steady-state concentrations from a zero starting concentration after simulated joint lavage, and (3) the clearance rate of HA from the joint after simulated therapeutic HA injection. The validity of the model was assessed by comparison of the lubricant concentrations predicted at steady-state with those observed in vivo.

\section{Model}

\section{Model Overview}

The model consists of a SF compartment surrounded by articular cartilage and a semi-permeable synovial membrane that separates the SF from an underlying subsynovium (SUB) compartment (Fig. 2). Lubricants are secreted into the SF by chondrocytes in articular cartilage (AC) and synoviocytes in the synovium (SYN). Some lubricants are lost from the SF by either degradation or flux through the membrane into the SUB; however, the synovium offers sufficient outflow resistance to retain a large pool of lubricant macromolecules in the SF. Transient accumulation of lubricants exists in the SF compartment until the system reaches a steady-state lubricant composition. A complete list of variables and parameters included in the model are shown in Table 1. 


\section{Governing Equations}

The rate of change in mass of lubricant $i(i=\mathrm{PRG} 4, \mathrm{HA}$, or SAPL) that has a concentration of $c_{i}^{S F}$ in a SF volume of $V^{S F}$ is assumed to depend on the secretion rate of $i$ by AC $\left(r_{i}^{A C}\right)$ and $\mathrm{SYN}\left(r_{i}^{S Y N}\right)$ of areas $A^{A C}$ and $A^{S Y N}$, the degradation rate of $i$ in $\operatorname{SF}\left(d_{i}\right)$, and the flux of $i$ across the synovial membrane area $\left(J_{i}^{S Y N}\right)$. All parameters are also a function of time, $t$, and the environment, which is described by the parameter $\alpha$ and includes chemical and mechanical factors.

A mass balance applied to the SF compartment results in:

$\frac{\partial\left[V^{S F}(t, \alpha) \cdot c_{i}^{S F}(t, \alpha)\right]}{\partial t}=r_{i}^{S Y N}(t, \alpha) \cdot A^{S Y N}(t, \alpha)+r_{i}^{A C}(t, \alpha) \cdot A^{A C}(t, \alpha)-d_{i}(t, \alpha)-J_{i}^{S Y N}(t, \alpha)(1)$

The degradation rate of $i\left(d_{i}\right)$ is dependent upon the concentration and activity of degradative enzyme in SF. For example, the protein PRG4 may be targeted by various enzymes, and in particular has been shown to be degraded by elastase (Elsaid et al., 2005). As shown by that study in a rabbit knee model of acute injury, injured SF had an elastase activity level of 1-4 $\mu$ units/ml, or about $0.2-0.6$ $\mathrm{pg} / \mathrm{ml}$ of elastase $(1 \mathrm{mg}=\sim 6.8$ units $)$ Application of $7 \mu \mathrm{g}$ of elastase to $5 \mu \mathrm{g}$ of PRG4 resulted in complete degradation of PRG4 within 2-6 hours. Thus, $d_{i}$ can be of the form:

$$
d_{i}(t, \alpha)=X(t, \alpha) \cdot Y(t, \alpha) \cdot c_{i}^{S F}(t, \alpha) \cdot V^{S F}(t, \alpha)
$$

where $X$ is the ratio of concentration of degradative enzyme

Table 1 List of variables and parameters

\begin{tabular}{|c|c|c|}
\hline $\begin{array}{l}\text { Variable } \\
\text { or parameter }\end{array}$ & Units & Description \\
\hline$i$ & & PRG4, HA \\
\hline$c_{i}^{S F}$ & $\mathrm{mg} / \mathrm{ml}$ & Concentration of $i$ in synovial fluid \\
\hline$c_{i}^{\text {SUB }}$ & $\mathrm{mg} / \mathrm{ml}$ & Concentration of $i$ in subsynovium \\
\hline$J_{i}^{S Y N}$ & $\mathrm{mg} / \mathrm{s}$ & Total flux of $i$ through membrane area \\
\hline$J_{i, d i f f}^{S Y N}$ & $\mathrm{mg} / \mathrm{s}$ & Flux of i due to diffusion \\
\hline$J_{i, \text { Conv }}^{\text {lall }}$ SYN & $\mathrm{mg} / \mathrm{s}$ & Flux of i due to fluid convection \\
\hline$J_{v}^{1, S Y N}$ & $\mathrm{ml} / \mathrm{s}$ & Fluid flow rate out of the synovium \\
\hline$p_{i}^{\text {SYN }}$ & $\mathrm{cm} / \mathrm{s}$ & Permeability of $i$ through synovium \\
\hline$p_{i}^{I N T}$ & $\mathrm{~cm} / \mathrm{s}$ & Permeability of i through interstitial space, or extracellular space \\
\hline$\Delta \pi_{\mathrm{i}}$ & $\mathrm{cm} \mathrm{H}_{2} 0$ & Osmotic pressure diff. of SF and SUB \\
\hline$\Delta P^{S Y N}$ & $\mathrm{~cm} \mathrm{H}_{2}^{2} 0$ & Hydrostatic pressure diff. of SF and SUB \\
\hline$k_{i}$ & $\mathrm{~cm} /\left(\mathrm{s} \bullet \mathrm{cm} \mathrm{H} \mathrm{H}_{2} 0\right)$ & Hydraulic conductance of synovium \\
\hline$r_{i}^{\text {SYN }}$ & $\mathrm{mg} /\left(\mathrm{cm}^{2} \cdot \mathrm{s}\right)$ & Secretion rate of $i$ by synoviocytes (SYN) \\
\hline$r_{i}^{A C}$ & $\mathrm{mg} /\left(\mathrm{cm}^{2} \bullet \mathrm{s}\right)$ & Secretion rate of $i$ by articular cartilage (AC) \\
\hline$d_{i}$ & $\mathrm{mg} / \mathrm{s}$ & Degradation rate of $i$ in synovial fluid \\
\hline$A^{S Y N}$ & $\mathrm{~cm}^{2}$ & Area of synovial membrane \\
\hline$A^{A C}$ & $\mathrm{~cm}^{2}$ & Area of cartilage surfaces \\
\hline$L$ & $\mathrm{~cm}$ & Membrane thickness \\
\hline$t$ & $\mathrm{~s}$ & Time \\
\hline$\alpha$ & & Environmental factor \\
\hline$V^{S F}$ & $\mathrm{ml}$ & Volume of synovial fluid \\
\hline$D_{i}$ & $\mathrm{~cm}^{2} / \mathrm{s}$ & Diffusion coefficient of $i$ in free solution \\
\hline$D_{i}^{i}$ SYN & $\mathrm{cm}^{2} / \mathrm{s}$ & Restricted diffusion coeff. of $i$ in synovium \\
\hline$\phi_{i}$ & & Partition coefficient of $\mathrm{i}$ for synovium \\
\hline$\sigma_{i}$ & & Reflection coefficient of $i$ for synovium \\
\hline$\theta_{\text {cell }}$ & & Volume fraction of cells in synovium \\
\hline$\theta_{\text {col }}^{\text {cell }}$ & & Volume fraction of collagen in synovium \\
\hline$\theta_{G A G}$ & & Polymer volume fraction in GAG matrix \\
\hline$\rho_{i}$ & $\mathrm{mg} / \mathrm{ml}$ & Density of i \\
\hline$a_{G A G}$ & $\mathrm{~nm}$ & Radius of GAG chains in synovium \\
\hline$a_{i}$ & $\mathrm{~nm}$ & Radius of $i$ \\
\hline$\zeta_{\mathrm{col}}$ & & Tortuosity due to collagen fibrils \\
\hline$\zeta_{\text {cell }}$ & & Tortuosity due to cells \\
\hline
\end{tabular}

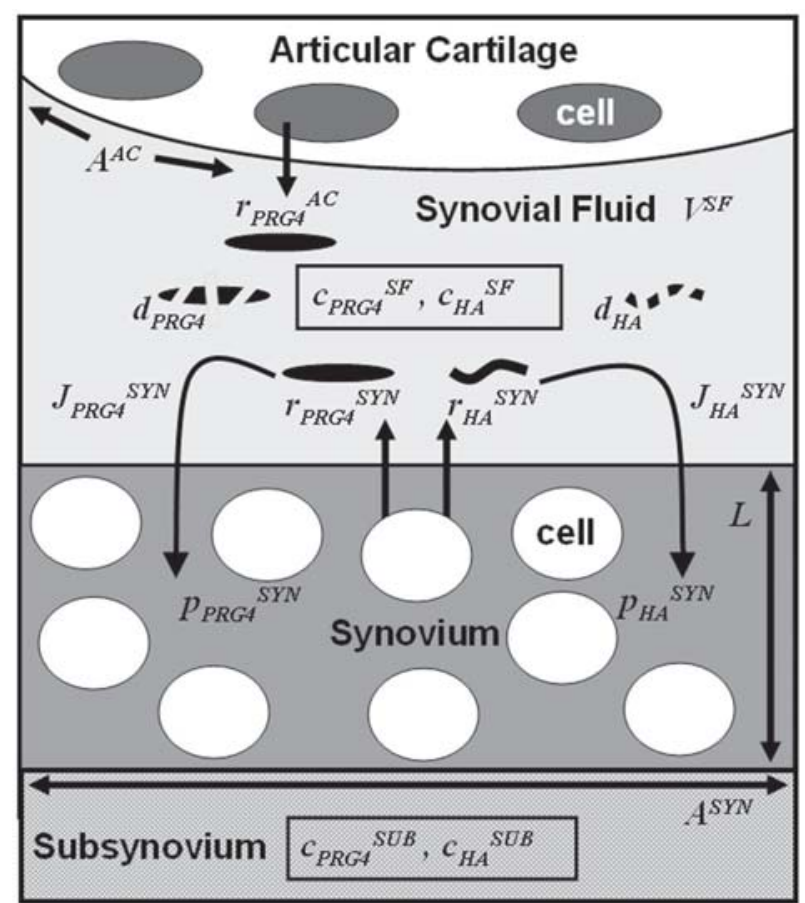

Figure 2. Schematic of synovial fluid composition model. Cartilage and synovium form a compartment around the synovial fluid, where lubricants secreted by the chondrocytes and synoviocytes are retained by the semi-permeable synovium. See Table 1 for a complete list of variables. 
in SF to the concentration of lubricant in SF, and $Y$ is the mass of substrate degraded per mass of enzyme per unit time. A similar analysis can be performed for other degradative enzymes that target PRG4, and also for enzymes present in SF that degrade HA, such as hyaluronidase.

The flux of lubricants $\left(J_{i}^{S Y N}\right)$ across the membrane is a sum of the solute flux due to diffusion $\left(J_{i, d i f}^{S Y N}\right)$ and the solute flux due to convective fluid flow $\left(J_{i, \text { diff }_{S Y N}}\right)$ :

$$
J_{i}^{S Y N}=J_{i, \text { diff }}^{S Y N}+J_{i, \text { conv }}^{S Y N}
$$

$J_{i, \text { diff }}^{\text {SYN }}$ is dependent upon the permeability $\left(p_{i}^{S Y N}\right)$ and area $\left(A^{S Y N}\right)$ of the synovial membrane and the concentration gradient between the $S F$ and $S U B$ compartments:

$$
J_{i, \text { diff }}^{\text {SYN }}(t, \alpha)=p_{i}^{S Y N}(t, \alpha) \cdot\left[c_{i}^{S F}(t, \alpha)-c_{i}^{S U B}(t, \alpha)\right] \cdot A^{S Y N}(t, \alpha)(4)
$$

$J_{i, \text { conv }}^{S Y N}$ is dependent upon the fluid flow out of the membrane $\left(J_{v}{ }^{S Y N}\right)$, the reflection coefficient of the membrane $\left(\sigma_{i}\right)$, and the concentration of $i$ in $\mathrm{SF}\left(c_{i}^{S F}\right)$ (Curry, 1984; Patlak et al., 1963):

$$
J_{i, \text { conv }}^{S Y N}=J_{v}^{S Y N}\left(1-\sigma_{i}\right) \cdot c_{i}^{S F}
$$

$J_{v}^{\text {SYN }}$ can be described by the following expression for fluid flow across a leaky membrane (Kedem and Katchalsky, 1958):

$$
J_{v}{ }^{S Y N}=k\left[\Delta P^{S Y N}(t, \alpha)-\sigma_{i}(t, \alpha) \Delta \pi_{i}(t, \alpha)\right] \cdot A^{S Y N}(t, \alpha)
$$

where $\Delta P^{S Y N}$ is the hydrostatic pressure difference and $\Delta \pi$. is the osmotic pressure difference between SF and SUB compartments, respectively, and $k$ is the hydraulic conductance of the synovium.

\section{Membrane Permeability}

Lubricant transport through the synovium occurs around the spaces, or volume fractions, occupied by synoviocytes $\left(\theta_{\text {cell }}\right)$ and collagen fibrils $\left(\theta_{\text {col }}\right)$, and around the polymer volume fraction of glycosaminoglycans $\left(\theta_{G A G}\right)$, and is further limited by the tortuosity of the pathway imposed by the cells $\left(\zeta_{\text {cell }}\right)$ and collagen fibrils $\left(\zeta_{c o l}\right)$ (Levick, 1994). Thus, there is restricted diffusion of lubricants within the synovium compared to diffusion in free solution. The restricted diffusion coefficient $\left(D_{i}^{S Y N}\right)$ for a globular solute within the GAG matrix of synovium is related to the diffusion coefficient in free solution $\left(D_{i}\right)$, $\theta_{G A G}$, the radius of GAG chains $\left(a_{G A G}\right)$, and the effective radius of the solute $\left(a_{i}\right)$ (Ogston et al., 1973):

$$
D_{i}^{S Y N}(t, \alpha)=D_{i} \cdot e^{\left\{-\sqrt{\theta_{G A G}(t, \alpha)} \cdot\left(1+\frac{a_{i}}{a_{G A G}}\right)\right\}}
$$

The $a_{i}$ can be taken as the Stokes-Einstein equivalent radius of a solute, estimated from its molecular weight $(M W)$ and density $(\rho)$, according to the following, where $N_{a}$ is Avogadro's number (Tanford, 1961):

$$
a_{i}=\left(\frac{3 \cdot M W}{4 \cdot \pi \cdot \rho \cdot N_{a}}\right)^{1 / 3}
$$

The permeability associated with the interstitial, or extracellular, space $\left(p_{i}^{I N T}\right)$ is a function of the restricted diffusion coefficient of the lubricant in the matrix $\left(D_{i}^{S Y N}\right)$, the partition coefficient $\left(\phi_{i}\right)$, the volume fraction $\left(\theta_{\text {col }}\right)$ and tortuosity $\left(\zeta_{c o l}\right)$ of the impenetrable collagen matrix components, and the thickness of the membrane $(L)$ (Levick, 1994):

$$
p_{i}^{I N T}(t, \alpha)=\frac{D_{i}^{S Y N}(t, \alpha) \cdot \phi_{i}(t, \alpha) \cdot\left[1-\theta_{c o l}(t, \alpha)\right] \cdot \zeta_{c o l}(t, \alpha)}{L}
$$

The $\phi_{i}$ of the lubricant in the matrix represents the ratio of the available solute space to the space occupied by the GAGs. The fractional space available to the solute $\left(K_{A V}\right)$ is given by the Ogston relation (Ogston et al., 1973).

$$
K_{A V}(t, \alpha)=e^{\left\{-\frac{\theta_{G A G}(t, \alpha)}{a_{G A G}{ }^{2}} \cdot\left(a_{G A G}+a_{i}\right)^{2}\right\}}
$$

The $\phi_{i}$ is related to $K_{A V}$ by the following (Curry, 1984):

$$
\phi_{i}(t, \alpha)=\frac{K_{A V}(t, \alpha)}{e^{-\theta_{G A G}}}
$$

Finally, the permeability of the entire synovium $\left(p_{i}^{S Y N}\right)$ to the lubricant $i$ is a function of the interstitial permeability $\left(p_{i}^{I N T}\right)$, and also the volume fraction $\left(\theta_{\text {cell }}\right)$ and tortuosity $\left(\zeta_{\text {cell }}\right)$ imposed by the impenetrable synoviocytes in the membrane (Levick, 1994):

$$
p_{i}^{\text {SYN }}(t, \alpha)=p_{i}^{I N T}(t, \alpha) \cdot\left[1-\theta_{\text {cell }}(t, \alpha)\right] \cdot \zeta_{\text {cell }}(t, \alpha)
$$

\section{Non-dimensional equations}

The governing equations of the model can be nondimensionalized by defining non-dimensional concentration $\left(c_{i}{ }^{S F}\right)$, secretion rates $\left(r_{i}{ }^{{ }^{S Y N}}, r_{i}{ }^{{ }^{A C}}\right)$, degradation rate $\left(d_{i}{ }^{\prime}\right)$ and time $\left(t^{\prime}\right)$ :

$$
\begin{aligned}
& C_{i}{ }^{S F}=\frac{C_{i}^{S F}}{C_{i, \text { basal }}^{S F}} \\
& r_{i}^{\prime S Y N}=\frac{r_{i}^{S Y N}}{r_{i, \text { basal }}^{S Y N}} \\
& r_{i}^{\prime A C}=\frac{r_{i}^{A C}}{r_{i, \text { basal }}^{A C}} \\
& d_{i}{ }^{\prime}=\frac{d_{i}}{d_{i, \text { basal }}} \\
& t^{\prime}=\frac{t}{\tau_{i}}
\end{aligned}
$$


After substitution and simplification, a non-dimensional mass balance governing equation results:

$$
\frac{\partial c_{i}{ }^{S F}}{\partial t^{\prime}}=k_{1} r_{i}{ }^{S Y N}+k_{2} r_{i}{ }^{A C}-k_{3} d_{i}{ }^{\prime}-c_{i}{ }^{S F}
$$

The non-dimensional parameters, $k_{1}, k_{2}, k_{3}$, and the dimensional $\tau_{i}$ are defined below:

$$
\begin{gathered}
k_{1}=\frac{r_{i, \text { basal }}^{\text {SYN }}}{p_{i}^{\text {SYN } C_{i, \text { basal }}^{S F}}} \\
k_{2}=\frac{A^{A C} r_{i, \text { basal }}^{A C}}{A^{S Y N} p_{i}^{S Y N} C_{i, \text { basal }}^{S F}} \\
k_{3}=\frac{d_{i, \text { basal }}}{A^{S Y N} p_{i}^{S Y N} C_{i, \text { basal }}} \\
\tau_{i}=\frac{V^{S F}}{p_{i}^{S Y N} A^{S Y N}}(22)
\end{gathered}
$$

\section{Model Assumptions}

General assumptions. It is assumed that the only parameters in the model that are altered with changes in the chemical environment (i.e. are a function of $a$ ) are the lubricant secretion rates and the dependent lubricant concentration. It is also assumed that the concentration of lubricants in the SUB compartment is zero for all situations, as transported fluid and solutes drain away via the system of lymphatics along intermuscular connective tissue planes (Jensen et al., 1993; Levick, 1980a; Levick, 1980b).

$$
c_{i}^{S U B}(t, \alpha)=0
$$

SF volume is kept in a steady-state, as the filtration of fluid across the capillary wall into SF occurs at a rate equal to that of lymph flow (Levick, 1987). It is also assumed that the degradation of lubricants is negligible compared to cellular secretion rates:

$$
d_{i}(t, \alpha)=0
$$

Additionally, the flux of lubricants due to fluid convection is also considered negligible compared to the flux due to diffusion, as the ratio of convective transport of solute to diffusive transport of solute was estimated for albumin to be $<<1$ (McDonald and Levick, 1993):

$$
J_{i, \text { conv }}(t, \alpha)=0
$$

Further support for this assumption comes from the fact that convective fluid flow out of the joint cavity may be attenuated by SF osmotic pressure at high lubricant concentrations, and also by a concentration polarization phenomenon for large molecules in SF such as HA (McDonald and Levick, 1992; Sabaratnam et al., 2004; Scott et al., 2000).
Case 1: Steady-state. The concentration of lubricants at steady-state will not change with time:

$$
\frac{\partial c_{i}^{S F}}{\partial t}(t=\infty, \alpha)=0
$$

Case 2: Joint lavage. After joint lavage, the concentration of lubricants in the SF will be effectively reduced to zero:

$$
c_{i}^{S F}(t=0, \alpha)=0
$$

The secretion rates with no chemical stimulation will be considered to be basal levels. Also, the volume of SF will be unaffected by the lavage procedure as any volume of fluid that remains in the joint and exceeds normal SF volume will be removed quickly. The transynovial flow rate of water is normally $\sim 5-10 \mu \mathrm{l} / \mathrm{min}$ at an intraarticular pressure of $\sim 2 \mathrm{cmH}_{2} \mathrm{O}$ (flexed knee joint), but under raised intraarticular pressures of $\sim 20 \mathrm{cmH}_{2} \mathrm{O}$ (chronic joint effusion) that occur with large increases in SF volume, is $\sim 20-40 \mu \mathrm{l} / \mathrm{min}$ (Coleman et al., 1998b; Scott et al., 1997). Thus, the SF volume of $\sim 1 \mathrm{ml}$ in normal human knee joints turns over in $\sim 1-2 \mathrm{hrs}$, and portions of volumes in excess of this would likely equilibrate in $<1 \mathrm{hr}$.

Case 3: HA injection. Prior to the injection, the concentration of HA in SF will be equal to that achieved at steady-state:

$$
c_{H A}^{S F}\left(t=0^{-}, \alpha\right)=c_{H A}^{S F}(t=\infty, \alpha)
$$

HA injections are generally on the order of $20 \mathrm{mg}$ (Tehranzadeh et al., 2005), and this will represent the bolus of HA introduced into the joint.

$$
c_{H A}^{S F}\left(t=0^{+}, \alpha\right)=c_{H A}^{S F}\left(t=0^{-}, \alpha\right)+\frac{20 m g}{V^{S F}}
$$

The volume of SF will also be unaffected by this procedure due to the relatively high transynovial flow rate of water, particularly at raised intraarticular pressures and volumes. With a flow rate of $\sim 20-40 \mu \mathrm{l} / \mathrm{min}$ (Coleman et al., 1998b; Scott et al., 1997), a typical injection of $2 \mathrm{ml}$ buffer solution would drain in $\sim 1-2 \mathrm{hr}$.

\section{Model Parameters}

Values for parameters used in the model are based on published values in the literature. The properties of cartilage, synovium, and synoval fluid utilized in the model include cartilage and synovium surface area, synovial fluid volume, and organization of the synovium relating to transynovial transport. The total surface area in the human knee joint is $121 \mathrm{~cm}^{2}$ for cartilage (Eckstein et al., 2001) and $277 \mathrm{~cm}^{2}$ for synovium (Davies, 1946), and the synovial fluid volume enclosed by these surfaces is $1.1 \mathrm{ml}$ (Ropes et al., 1940). The synovium, which is $50 \mu \mathrm{m}$ thick in humans (Price et al., 1995), has a cell volume fraction varying from 0.42 at the surface to 0.67 in deeper layers and a tortuosity due to the cells of 0.69 (Levick and McDonald, 1989a; Levick and McDonald, 1989b). The 
volume fraction due to collagen is 0.2 (Levick, 1994) and the tortuosity is 0.70 (Maroudas, 1970; Sullivan and Hertel, 1942). The portion of synovium through which lubricants travel contains GAG chains with radii of $0.56 \mathrm{~nm}$ (Ogston et al., 1973) and a volume fraction of 0.0075 (Sabaratnam et al., 2005; Scott et al., 2003).

The molecular weight forms of PRG4 that have been isolated from SF and cartilage exist in the range of 220 $\mathrm{kDa}$ (Swann et al., 1977) to $345 \mathrm{kDa}$ (Schumacher et al., 1994), while HA exists in the range of 2000-6000 kDa (Fraser et al., 1997). The mass density for both PRG4 and HA is $1.45 \mathrm{~g} / \mathrm{ml}$ (Mahlbacher et al., 1992; Mason et al., 1982; Swann et al., 1981). These parameters were used together to calculate a range of PRG4 and HA radii, assuming the idealized case that they exist in SF as globular solutes.

Diffusion coefficients have been determined for PRG4 and HA in free solution, and are $1.11 \times 10^{-7} \mathrm{~cm}^{2} / \mathrm{s}$ (Swann et al., 1981) and $9.8 \times 10^{-8} \mathrm{~cm}^{2} / \mathrm{s}$ (Lu et al., 2005), respectively. These free diffusion coefficients were used with the above parameter values of tissue and lubricant properties to calculate restricted diffusion and also permeability of lubricants through synovium.

Secretion rates used in the model depend on the regulatory factors present in the system, and are different under basal, TGF- $\beta$ (10 ng/ml), and IL-1 (10 ng/ml) conditions. IL-1 downregulates PRG4 secretion by chondrocytes from $2.89 \times 10^{-7} \mathrm{mg} /\left(\mathrm{cm}^{2} \cdot \mathrm{s}\right)$ to $1.16 \times 10^{-7}$ $\mathrm{mg} /\left(\mathrm{cm}^{2} \cdot \mathrm{s}\right)$, while TGF- $\beta$ upregulates PRG4 secretion to $1.16 \times 10^{-6} \mathrm{mg} /\left(\mathrm{cm}^{2} \cdot \mathrm{s}\right)$ (Flannery et al., 1999; Schmidt et al., 2005). Synoviocyte PRG4 secretion is similarly regulated by these cytokines, as IL-1 downregulates secretion from $4.05 \times 10^{-9} \mathrm{mg} /\left(\mathrm{cm}^{2} \cdot \mathrm{s}\right)$ to $2.43 \times 10^{-9} \mathrm{mg} /$ $\left(\mathrm{cm}^{2} \cdot \mathrm{s}\right)$, and TGF- $\beta$ upregulates secretion to $2.23 \times 10^{-8}$ $\mathrm{mg} /\left(\mathrm{cm}^{2} \cdot \mathrm{s}\right)$ (unpublished data). TGF- $\beta$ and IL-1 result in increased HA secretion by synoviocytes, rising from 2.84 x $10^{-9} \mathrm{mg} /\left(\mathrm{cm}^{2} \cdot \mathrm{s}\right)$ to $6.72 \times 10^{-8} \mathrm{mg} /\left(\mathrm{cm}^{2} \cdot \mathrm{s}\right)$ and $9.95 \times 10^{-8}$ $\mathrm{mg} /\left(\mathrm{cm}^{2} \cdot \mathrm{s}\right)$, respectively (Haubeck et al., 1995). Cellular secretion rates for synoviocytes were converted to tissue secretion rates using a $\sim 0.8$ surface area fraction of synovium occupied by synoviocytes (Price et al., 1995) and assuming a typical cell diameter of $\sim 16 \mu \mathrm{m}$.

\section{Solutions}

Using the parameter values above and listed in Table 2 , the first-order system of ordinary differential equations were solved numerically using Matlab 7.0 (The MathWorks, Natick, MA). Results are given for both the low and high end of the predicted concentration range for each lubricant. General concentration profiles are also presented as a function of the non-dimensional constants and $\tau_{i}$.
Table 2 Values used in the model. TGF- $\beta$ and IL-1 values are for a concentration of $10 \mathrm{ng} /$ $\mathrm{ml}$.

\begin{tabular}{|c|c|c|c|c|c|}
\hline Variable & Units & Value (basal) & (TGF- $\beta)$ & (IL-1) & References \\
\hline$D_{H A}$ & $\mathrm{~cm}^{2} / \mathrm{s}$ & $9.80 \times 10^{-8}$ & & & $\mathrm{Lu}, 2005$ \\
\hline$D_{P R G 4}$ & $\mathrm{~cm}^{2} / \mathrm{s}$ & $1.11 \times 10^{-7}$ & & & Swann, 1981 \\
\hline$r_{H A} S Y N$ & $\mathrm{mg} /\left(\mathrm{cm}^{2} \bullet \mathrm{s}\right)$ & $2.84 \times 10^{-9}$ & $6.72 \times 10^{-8}$ & $9.95 \times 10^{-8}$ & Haubeck, 1995 \\
\hline$r_{P R G 4}^{A C}$ & $\mathrm{mg} /\left(\mathrm{cm}^{2} \bullet \mathrm{s}\right)$ & $2.89 \times 10^{-7}$ & $1.16 \times 10^{-6}$ & $1.16 \times 10^{-7}$ & Schmidt, 2005 \\
\hline$r_{P R G 4}^{S Y N}$ & $\mathrm{mg} /\left(\mathrm{cm}^{2} \bullet \mathrm{s}\right)$ & $4.05 \times 10^{-9}$ & $2.23 \times 10^{-8}$ & $2.43 \times 10^{-9}$ & unpublished data \\
\hline$A^{A C}$ & $\mathrm{~cm}^{2}$ & 121 & & & Eckstein, 2001 \\
\hline$A^{S Y N}$ & $\mathrm{~cm}^{2}$ & 277 & & & Davies, 1946 \\
\hline$V^{S F}$ & $\mathrm{ml}$ & 1.1 & & & Ropes, 1940 \\
\hline$L$ & $\mathrm{~cm}$ & 0.005 & & & Price, 1995 \\
\hline$\theta_{\text {cell }}$ & & $0.42-0.67$ & & & Levick, 1989a,b \\
\hline$\theta_{c o l}$ & & 0.2 & & & Levick, 1994 \\
\hline \multirow[t]{2}{*}{$\theta_{G A G}$} & & 0.0075 & & & Sabaratnam, 2005 \\
\hline & & & & & Scott, 2003 \\
\hline \multirow[t]{2}{*}{$\zeta_{c o l}$} & & 0.7 & & & Maroudas, 1970, \\
\hline & & & & & Sullivan, 1942 \\
\hline$\zeta_{\text {cell }}$ & & 0.69 & & & Levick, 1989a,b \\
\hline$a_{G A G}$ & $\mathrm{~nm}$ & 0.56 & & & Ogston, 1973 \\
\hline \multirow[t]{2}{*}{$\rho_{H A}$} & $\mathrm{~g} / \mathrm{ml}$ & 1.45 & & & Mahlbacher, 1992 \\
\hline & & & & & Mason, 1982 \\
\hline$\rho_{P R G 4}$ & $\mathrm{~g} / \mathrm{ml}$ & 1.45 & & & Swann, 1981 \\
\hline$M W_{H A}$ & $\mathrm{kDa}$ & $2000-6000$ & & & Fraser, 1997 \\
\hline \multirow[t]{2}{*}{$M W_{P R G 4}$} & $\mathrm{kDa}$ & $220-345$ & & & Swann, 1977 \\
\hline & & & & & Schumacher, 1994 \\
\hline
\end{tabular}




\section{Results}

\section{Case 1: Steady-state Lubricant Composition}

The form of the solution for $c_{i}^{S F}$ at steady-state is determined from equations 13-18,

$$
c_{i}^{S F}(t=\infty, \alpha)=c_{i, \text { basal }}^{S F}\left\{k_{1} \cdot \frac{r_{i}^{S Y N}(\alpha)}{r_{i, \text { basal }} S Y N}+k_{2} \cdot \frac{r_{i}^{A C}(\alpha)}{r_{i, \text { basal }}^{A C}}\right\}
$$

or equivalently, from equations 1 and 4 :

$$
c_{i}^{S F}(t=\infty, \alpha)=\frac{r_{i}^{S Y N}(\alpha)+r_{i}^{A C}(\alpha) \cdot \frac{A^{A C}}{A^{S Y N}}}{p_{i}^{S Y N}}
$$

The form of the equations shows that increases in $r_{i}^{A C}$ and $r_{i}^{S Y N}$ result in increases in $c_{i}^{S F}$. Increases in $k_{1}$ and $k_{2}$ also cause increases in $c_{i}^{S F}$, and can be achieved by decreases in $p_{i}^{S Y N}$ or increases in the ratio of $A^{A C}$ to $A^{S Y N}$.

A range of values has been noted for some of the parameters used in the model (Table 2), and thus there was a range of model predictions for lubricant concentrations in SF. Permeability ranged from $6.79 \times 10^{-7}$ $\mathrm{cm} / \mathrm{s}-1.56 \times 10^{-6} \mathrm{~cm} / \mathrm{s}$ for PRG4 and $1.73 \times 10^{-8} \mathrm{~cm} / \mathrm{s}-$ $1.84 \times 10^{-7} \mathrm{~cm} / \mathrm{s}$ for HA. The range of predictions for $C_{P R G 4} S F$ and $C_{H A}{ }^{S F}$ at steady-state under basal conditions was 0.08 $0.19 \mathrm{mg} / \mathrm{ml}$ and $0.02-0.16 \mathrm{mg} / \mathrm{ml}$, respectively. With TGF$\beta$ stimulation, $C_{P R G 4} S F$ increased to $0.34-0.77 \mathrm{mg} / \mathrm{ml}$ and $C_{H A}{ }^{S F}$ increased to $0.36-3.89 \mathrm{mg} / \mathrm{ml}$, while with IL-1 $C_{P R G 4}{ }_{S F}$ decreased to $0.03-0.08 \mathrm{mg} / \mathrm{ml}$ but $C_{H A}{ }^{S F}$ increased to 0.54 $5.77 \mathrm{mg} / \mathrm{ml}$ (Table 3).

\section{Transient Changes in Lubricant Composition}

The form of the solution for transient changes in $c_{i}^{S F}$ is determined from equations 13-18,

$$
\frac{\partial c_{i}^{S F}(\alpha, t)}{\partial t}=\frac{c_{i, b a s a l}{ }^{S F}}{\tau_{i}}\left\{k_{1} \frac{r_{i}^{S Y N}(\alpha)}{r_{i, \text { basal }}{ }_{S Y}}+k_{2} \frac{r_{i}^{A C}(\alpha)}{r_{i, \text { basal }}{ }_{A C}}-\frac{c_{i}^{S F}(\alpha, t)}{c_{i, \text { basal }}{ }^{S F}}\right\}
$$

or equivalently, from equations 1 and 4 :

$$
\frac{\partial c_{i}^{S F}(\alpha, t)}{\partial t}=\frac{r_{i}^{S Y N}(\alpha) \cdot A^{S Y N}+r_{i}^{A C}(\alpha) \cdot A^{A C}-p_{i}^{S Y N} \cdot c_{i}^{S F}(\alpha, t) \cdot A^{S Y N}}{V^{S F}}
$$

General curves with concentration plotted against time for conditions of joint lavage and HA injection are shown in Figure 3. This general case illustrates that steady state lubricant concentration levels are governed by the nondimensional constants $k_{1}$ and $k_{2}$ and secretion rates, while the temporal effects are governed by $\tau_{i}$. The parameter $\tau_{i}$

\begin{tabular}{|c|c|c|c|}
\hline \multirow{2}{*}{\multicolumn{2}{|c|}{ Condition }} & \multicolumn{2}{|c|}{ Concentration range $[\mathrm{mg} / \mathrm{ml}]$} \\
\hline & & PRG4 & HA \\
\hline & iological & $0.05-0.35$ & $1-4$ \\
\hline \multirow{3}{*}{ 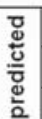 } & basal & $0.08-0.19$ & $0.02-0.16$ \\
\hline & TGF- $\beta$ & $0.34-0.77$ & $0.36-3.89$ \\
\hline & IL-1 & $0.03-0.08$ & $0.54-5.77$ \\
\hline
\end{tabular}

Table 3. Steady-state model predictions of ranges of synovial fluid lubricant composition under basal conditions or with $10 \mathrm{ng} / \mathrm{ml}$ of TGF- $\beta$ or IL-1.

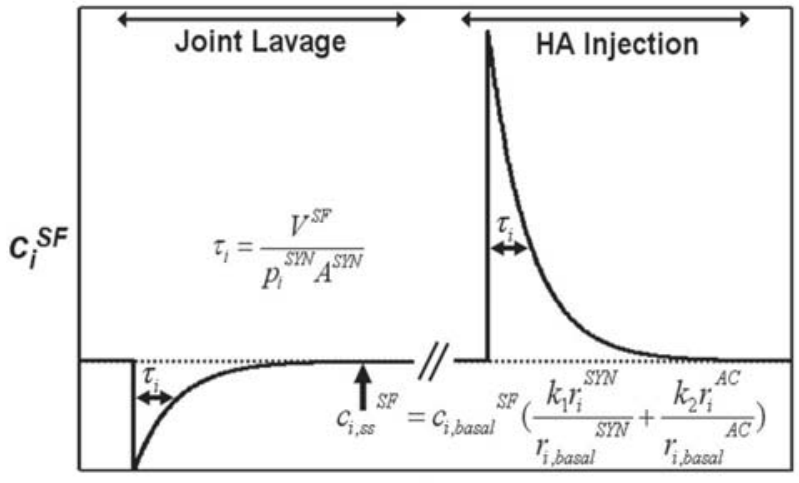

$t$

Figure 3. General curves of concentration plotted against time for conditions of joint lavage and HA injection, illustrating that steady state lubricant concentration levels are governed by the nondimensional constants $k_{1}$ and $k_{2}$ and secretion rates, while the temporal effects are governed by $\tau_{i}$.

describes the kinetics of lubricant concentration in SF, and represents the time to reach $63 \%$ of the steady state concentration after joint lavage, or time for $63 \%$ of injected HA to be cleared from the SF. The form of $\tau_{i}$ shows that increases in $p_{i}^{S Y N}$ and $A^{S Y N}$ result in decreases in $\tau$ i, while increases in $V^{S F}$ cause increases in $\tau_{i}$. Numerical values for transient and steady state lubricant concentrations in the different cases are discussed below.

\section{Case 2: Joint Lavage}

After joint lavage, the starting concentration of lubricants in SF was decreased in a step-wise manner to $0 \mathrm{mg} / \mathrm{ml}$ at $\mathrm{t}=0$ and returned to the predicted steady-state concentration with kinetics that were markedly different for PRG4 and HA. The range of time constants, which indicate the time to reach $63 \%$ of steady-state concentration of lubricant in SF were 0.03-0.07 days for PRG4 (Fig. 4a,b) and 0.252.66 days for HA (Fig. 4c,d). Chemical stimulation with TGF- $\beta$ and IL- 1 is not predicted to alter the kinetics of lubricant restoration following joint lavage; however, as noted for steady-state predictions, TGF- $\beta$ and IL- 1 dictated the magnitude attained at steady-state.

\section{Case 3: Therapeutic HA Injection}

After an HA injection of $20 \mathrm{mg}$, the concentration of HA in SF increased by $18.2 \mathrm{mg} / \mathrm{ml}$ and then returned to steadystate concentration after a duration of time (Fig. 5a,b). The time for $63 \%$ of the injected HA to be cleared from the joint, was 0.25-2.66 days. As stated above, chemical stimulation with TGF- $\beta$ and IL-1 did not alter the kinetics associated with HA injection, but dictated the magnitude of the final steady-state concentration.

\section{Discussion}

This study describes some essential features of steady-state and kinetic SF lubricant composition in whole joints under normal or altered chemical environments, and also with different therapeutic interventions. The model predicts steady-state lubricant concentrations that are consistent 

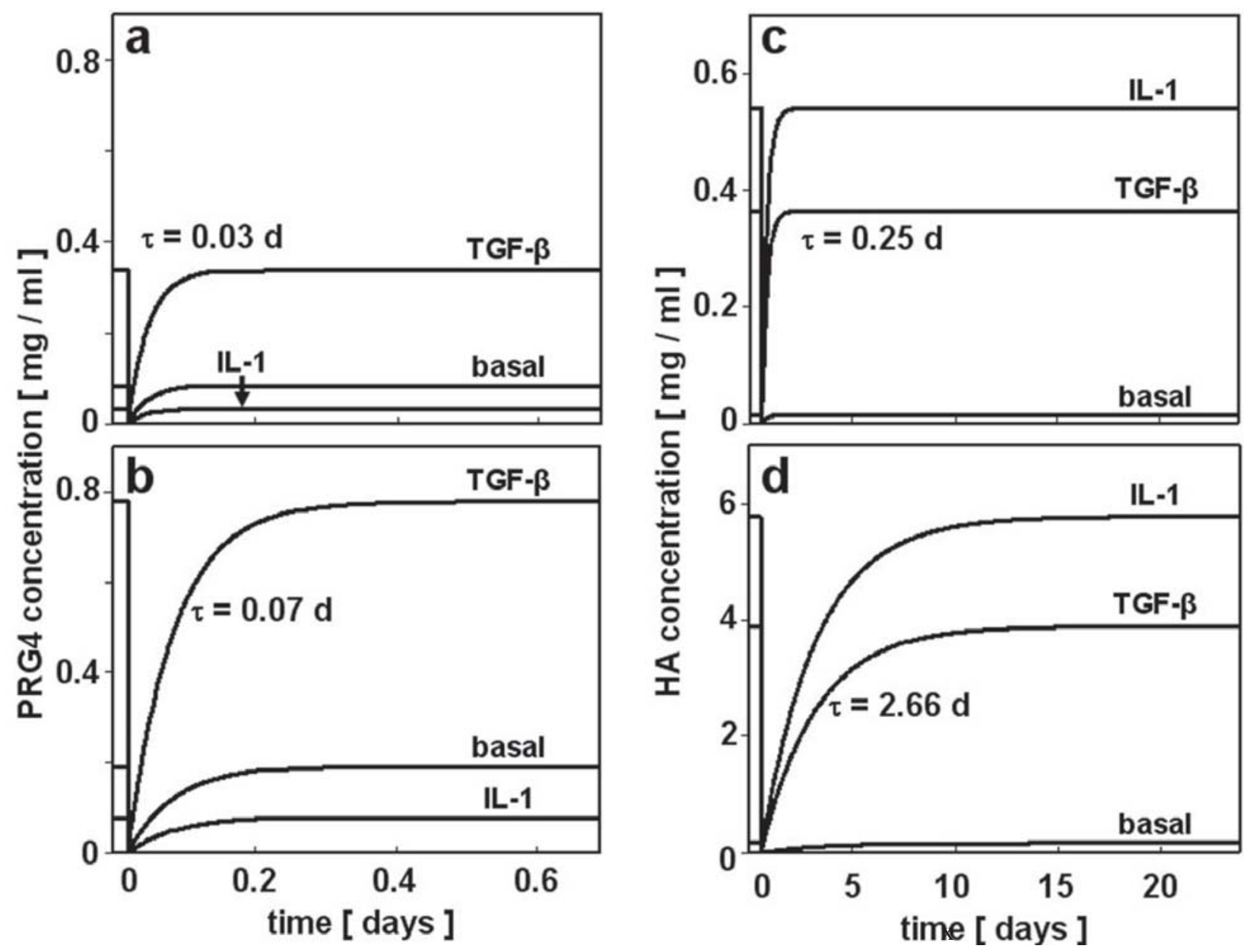

Figure 4. Transient rise in synovial fluid lubricant concentration after joint lavage, with or without chemical regulatory factors, and associated time constants, $\tau$. (a) low end PRG4 predictions, (b) high end PRG4 predictions, (c) low end HA predictions, and (d) high end HA predictions.

with physiologically observed concentrations. Further, chemical alterations in the synovial joint environment that may occur in injury and disease were predicted to alter lubricant concentration. The kinetics associated with joint lavage predicted that PRG4 and HA achieve steady-state concentration on distinct time scales. Finally, therapeutic injection of HA into SF was predicted to cause an immediate increase in HA concentration, which returns to steady-state concentration after $\sim 1-2$ days.

The quantitative intercompartmental model developed in this study included several assumptions that allowed for a straightforward analysis that could be expanded upon. For example, the model could be extended by including additional environmental factors and allowing a number of parameters to change with the environment and time. Some parameters in the model are also described in bulk and spatially averaged terms rather than on multiple scale levels. Finally, physical and chemical interactions of lubricants with their environment were not considered in the model, and may affect the free concentration of lubricants in SF.

While lubricant secretion rates were the sole variables in the model that were assumed to be dependent on chemical factors, other variables and parameters included in the model may also be affected by these and other environmental factors. Such environmental factors can include mechanical stimuli that are also known to regulate lubricant secretion by both chondrocytes and synoviocytes. Compressive forces downregulate PRG4 secretion by chondrocytes, while shear forces upregulate PRG4 secretion (Nugent et al., 2006a; Nugent et al., 2006b). Mechanical stretching of synovium results in increased HA secretion by synoviocytes (Momberger et al., 2005). Both chemical and mechanical factors may affect not only lubricant secretion, but also parameters that influence permeability of the synovial membrane. For example, different cytokines may have anabolic or catabolic effects on the extracellular matrix of synovium and thus alter its composition and organization. The increased permeability of the synovium in rheumatoid arthritis may possibly reflect such a phenomenon (Levick, 1981). Joint motion involving stretching of the synovium may result in changes in thickness and area of the membrane, leading to altered permeability. Chemical and mechanical factors may also affect synovium permeability by regulating aspects of lubricant metabolism, such as the molecular weight form of lubricant that is secreted. In the SF of arthritic joints, HA exists at a lower molecular weight (Balazs, 1980; Dahl et al., 1985), while in normal SF, PRG4 may exist in both monomeric and multimeric forms (Plaas et al., 2006). 


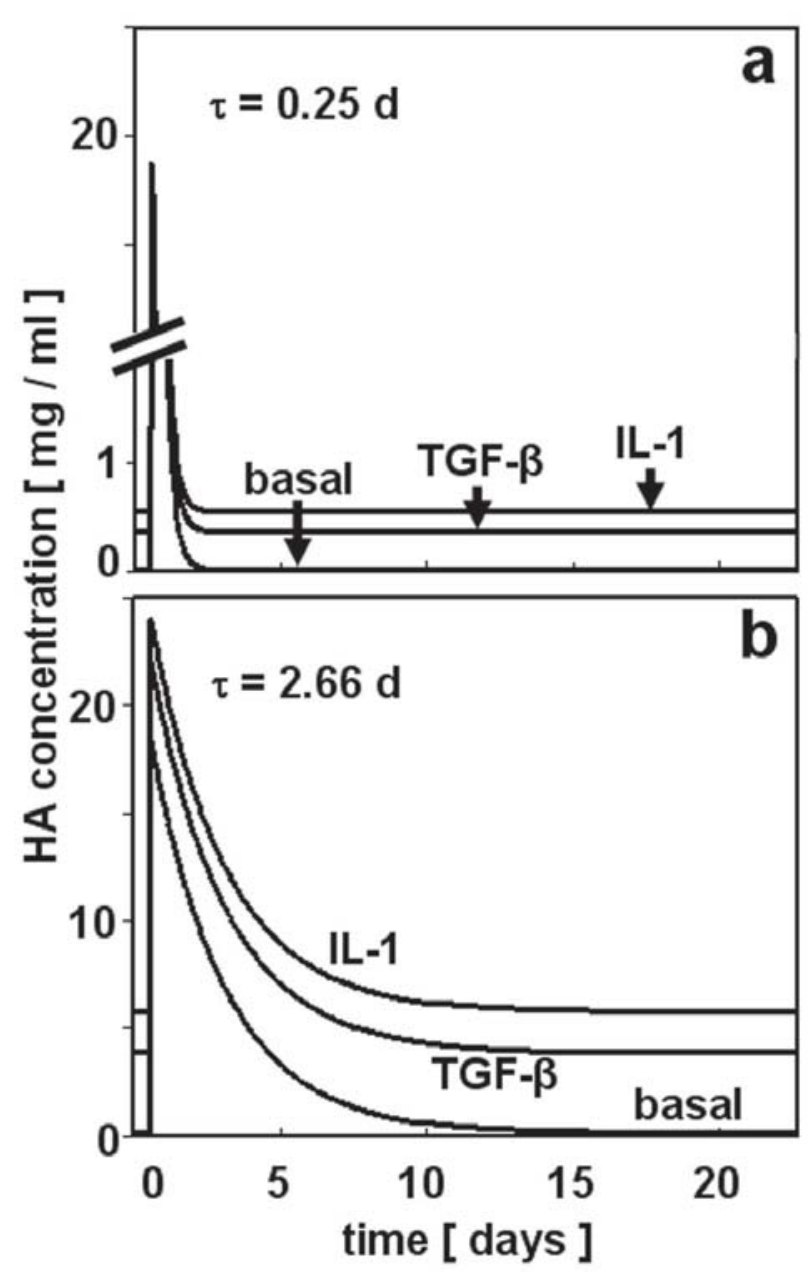

Figure 5. Transient changes in synovial fluid lubricant concentration after therapeutic HA injection, with or without chemical regulatory factors, and associated time constants, $\tau$. (a) low end HA predictions and (b) high end HA predictions.

Changes in any of these parameters that affect permeability to lubricants may also alter the rate at which fluid is transported across the synovial membrane. The direction, i.e. entry or exit, of this fluid transport may similarly be controlled by chemical and mechanical factors, such as osmotic pressure exerted by SF molecules and hydrostatic pressure due to joint flexion and extension. Thus, changes in parameters that affect permeability may subsequently lead to changes in SF volume. Such concomitant alterations in membrane area and permeability, SF volume, and the turnover of SF are observed in cases of joint swelling associated with injury or disease (Levick, 1990; Wallis et al., 1987).

The parameters of the compartmental model may be taken as a macroscopic representation of processes occurring on multiple scales, each of which may have distinct spatial and temporal characteristics. For example, the matrix composition of the synovium may be affected by cytokines that alter the content of a specific collagen type. The current model reflects this change only in the lumped parameters that represent total collagen volume fraction and tortuosity, and thus does not attempt to discriminate details on this scale. The model also does not reflect alterations in gene expression for either lumped or specific components. At each of these scales, tissue properties may vary throughout the total area or volume, and triggered events may occur over distinct time scales for different components.

Interactions of lubricants with themselves, other lubricants, or with surrounding tissues could also be included in the model. For example, PRG4 may interact with itself, as both monomeric and multimeric forms have been observed (Plaas et al., 2006). HA may also be influenced by its own presence, as secretion by synoviocytes can depend upon the concentration and molecular weight form of HA in the environment of the synoviocytes (Smith and Ghosh, 1987). Lubricant molecules may also interact with each other. In particular, the putative lubricant surface active phospholipid (SAPL) may bind to HA or PRG4 and be carried in SF by these molecules (Hills, 2000). It should be noted that SAPL was not examined in this model as there is conflicting evidence on its role in joint lubrication (Hills and Crawford, 2003; Jay and Cha, 1999). However, its behaviour indicates that interactions between molecules in SF do exist. Electrostatic interactions between lubricants and the extracellular matrix of synovium, and binding of lubricants to tissues in the joint may also be important processes affecting SF lubricant composition.

Steady-state lubricant concentrations predicted by the model were generally consistent with those observed physiologically. The concentration of PRG4 in human SF ranges from $52-350 \mu \mathrm{g} / \mathrm{ml}$ in normal joints post-mortem, and increases to $276-762 \mu \mathrm{g} / \mathrm{ml}$ in SF obtained from patients undergoing arthrocentesis procedures (Schmid et al., 2001a). In acute injury in a rabbit knee model, PRG4 concentration decreased from $280 \mu \mathrm{g} / \mathrm{ml}$ to $20-100 \mu \mathrm{g} / \mathrm{ml}$ (Elsaid et al., 2005). Model predictions of $C_{P R G 4} S F$ at steadystate under basal conditions were comparable to that observed in normal SF in vivo. The model predicted an increased PRG4 concentration with TGF- $\beta$ stimulation but decreased concentration with IL-1, which may reflect distinct changes in the SF chemical environment that occur with different types of injury and disease. The concentration of HA in human SF ranges from 1-4 mg/ml in healthy individuals (Balazs, 1974; Chmiel and Walitza, 1980; Mazzucco et al., 2004; Watterson and Esdaile, 2000), and decreases after effusive joint injury (Asari et al., 1994) and in arthritic disease to $\sim 0.1-1.3 \mathrm{mg} / \mathrm{ml}$ (Dahl et al., 1985; Mazzucco et al., 2004). Model predictions of $c_{H A}{ }^{S F}$ under basal conditions were considerably below normal SF concentration. Stimulation with either TGF- $\beta$ or IL-1 increased $C_{H A}{ }^{S F}$ to the upper range of in vivo levels, which may indicate that a certain concentration of these cytokines is required in normal SF to achieve physiological concentrations of HA. The discrepancy between observed HA concentration in diseased joints and model predictions in an environment of increased cytokine concentration that may exist in injury and disease might result from allowing only lubricant secretion rates in the model to change as a function of the environment. As discussed previously, chemical stimuli may exert their effects on SF lubricant 
composition by altering the permeability of the synovium which may dominate over alterations in lubricant secretion rates.

The distinct kinetics of PRG4 and HA restoration after joint lavage have implications for disease and clinical therapies. For example, in acute injury, both PRG4 and HA concentrations are observed to decrease (Asari et al., 1994; Elsaid et al., 2005). Model predictions suggest that after the inflammation of an acute injury has cleared, the concentration of PRG4 may be restored relatively rapidly compared to the concentration of HA. The minimum concentration of lubricants in SF that is required to create a mechanically functional fluid is unknown. However, decreasing doses of SF and the PRG4 and HA constituents results in increased friction between articulating cartilage surfaces in a cartilage-on-cartilage friction test (Schmidt et al., 2007). If the joint lavage procedure challenges the low-friction, low-wear environment of synovial joints in the short term, it may prove beneficial to provide adjunctive therapies to normalize lubricant concentrations. Steroid supplementation is commonly given with joint lavage to help reduce inflammation (Frias et al., 2004; Tanaka et al., 2006), and more recently, HA supplementation has been given to enhance lubrication in the joint and decrease postprocedure pain (Mathies, 2006). The model predictions in this study support the use of lubricant supplementation to temporarily increase lubricant concentration in SF.

The clearance rate of HA predicted by the model after therapeutic injection is generally consistent with experimental reports, suggesting that this approach of analysis may be useful for putative therapies involving delivery of PRG4. The half-life of HA in SF has been studied in rabbit and sheep models, and is on the order of 24 hours for normal joints (Coleman et al., 1997; Laurent et al., 1992; Sakamoto et al., 1984), but decreases to $\sim 12$ hours in the case of induced arthritis in the sheep model (Fraser et al., 1993). In the present study, simulated therapeutic delivery of HA into SF resulted in a large instantaneous rise in concentration over the steady-state levels, but the model predicted that the injected HA appreciably cleared (i.e. 63\% cleared) after 0.25-2.66 days. This rate of clearance is also consistent with the periodic weekly injection of HA into diseased joints (Tehranzadeh et al., 2005). Clinical results of therapeutic HA injection can be highly dependent upon the molecular weight of HA (Ghosh and Guidolin, 2002; Moreland, 2003), possibly reflecting changes in synovium permeability and the halflife of this molecule in SF. Thus, the present model may have applications in comparing the kinetics of molecular concentrations with associated clinical outcomes.

The quantitative intercompartmental model of SF lubricant composition developed in this study may also have applications to a variety of current and future joint therapies. In partial or total knee arthroplasty, removal of the cartilage surface areas may affect lubricant concentration. In cell injection or transplantation therapies, the model may elucidate the effects of the cell sources on lubricant concentration. In engineering whole biological joints, the model may facilitate development of a mechanically functional bioengineered SF in a closed volume. Such bioengineering of fluid, as opposed to the traditional engineering of tissues, may be a critical component of a whole joint bioreactor system for creation of large contoured orthotopic tissue blocks for biological arthroplasty.

\section{Acknowledgments}

This work was supported by research grants from the National Institutes of Health, the National Science Foundation, and in part by a grant to UCSD, in support of RLS, from the Howard Hughes Medical Institute through the HHMI Professors Program, and by University of California Systemwide Biotechnology Research \& Education Program GREAT Training Grant 2006-17 (MEB).

\section{References}

Asari A, Miyauchi S, Sekiguchi T, Machida A, Kuriyama S, Miyazaki K, Namiki O (1994) Hyaluronan, cartilage destruction and hydrarthrosis in traumatic arthritis. Osteoarthritis Cartilage 2: 79-89.

Ashhurst DE, Bland YS, Levick JR (1991) An immunohistochemical study of the collagens of rabbit synovial interstitium. J Rheumatol 18: 1669-1672.

Athanasou NA, Quinn J (1991) Immunocytochemical analysis of human synovial lining cells: phenotypic relation to other marrow derived cells. Ann Rheum Dis 50: 311315.

Ayral X (2005) Arthroscopy and joint lavage. Best Pract Res Clin Rheumatol 19: 401-415.

Balazs E, Briller SO, Denlinger JL (1980) Nahyaluronate molecular size variations in equine and human arthritis synovial fluids and the effect on phagocytic cells. Osteoarth Symp Semin Arthritis Rheum Suppl 1: 141143.

Balazs EA (1974) In: Disorders of the Knee (A. J. Helfet) Lippincott Co., Philadelphia, 63-75.

Belcher C, Yaqub R, Fawthrop F, Bayliss M, Doherty M (1997) Synovial fluid chondroitin and keratan sulphate epitopes, glycosaminoglycans, and hyaluronan in arthritic and normal knees. Ann Rheum Dis 56: 299-307.

Bertone AL, Palmer JL, Jones J (2001) Synovial fluid cytokines and eicosanoids as markers of joint disease in horses. Vet Surg 30: 528-538.

Buckwalter JA, Mankin HJ (1997) Articular cartilage. Part II: degeneration and osteoarthrosis, repair, regeneration, and transplantation. J Bone Joint Surg Am 79: 612-632.

Cameron ML, Fu FH, Paessler HH, Schneider M, Evans CH (1994) Synovial fluid cytokine concentrations as possible prognostic indicators in the ACL-deficient knee. Knee Surg Sports Traumatol Arthrosc 2: 38-44.

Chmiel IH, Walitza E (1980) On the Rheology of Blood and Synovial Fluids. Research Studies Press, New York, 8-13.

Coleman P, Kavanagh E, Mason RM, Levick JR, Ashhurst DE (1998a) The proteoglycans and 
glycosaminoglycan chains of rabbit synovium. Histochem J 30: 519-524.

Coleman PJ, Scott D, Abiona A, Ashhurst DE, Mason RM, Levick JR (1998b) Effect of depletion of interstitial hyaluronan on hydraulic conductance in rabbit knee synovium. J Physiol 509: 695-710.

Coleman PJ, Scott D, Ray J, Mason RM, Levick JR (1997) Hyaluronan secretion into the synovial cavity of rabbit knees and comparison with albumin turnover. $\mathrm{J}$ Physiol 503: 645-656.

Curry F (1984) In: Handbook of Physiology (E. R. a. C. Michel) American Physiological Society, Bethesda, 309374.

Dahl LB, Dahl IM, Engstrom-Laurent A, Granath K (1985) Concentration and molecular weight of sodium hyaluronate in synovial fluid from patients with rheumatoid arthritis and other arthropathies. Ann Rheum Dis 44: $817-$ 822.

Davies DV (1946) Synovial membrane and synovial fluid of joints. Lancet 248: 815-822.

Dobbie JW, Hind C, Meijers P, Bodart C, Tasiaux N, Perret J, Anderson JD (1995) Lamellar body secretion: ultrastructural analysis of an unexplored function of synoviocytes. Br J Rheumatol 34: 13-23.

Eckstein F, Winzheimer M, Hohe J, Englmeier KH, Reiser M (2001) Interindividual variability and correlation among morphological parameters of knee joint cartilage plates: analysis with three-dimensional MR imaging. Osteoarthritis Cartilage 9: 101-111.

Elsaid KA, Jay GD, Warman ML, Rhee DK, Chichester CO (2005) Association of articular cartilage degradation and loss of boundary-lubricating ability of synovial fluid following injury and inflammatory arthritis. Arthritis Rheum 52: 1746-1755.

Fahlgren A, Andersson B, Messner K (2001) TGFbeta 1 as a prognostic factor in the process of early osteoarthrosis in the rabbit knee. Osteoarthritis Cartilage 9: 195-202.

Fava R, Olsen N, Keski-Oja J, Mose H, Pincus T (1989) Active and latent forms of transforming growth factor $\beta$ activity in synovial effusions. J Exp Med 169: 291-296.

Flannery CR, Hughes CE, Schumacher BL, Tudor D, Aydelotte MB, Kuettner KE, Caterson B (1999) Articular cartilage superficial zone protein (SZP) is homologous to megakaryocyte stimulating factor precursor and Is a multifunctional proteoglycan with potential growthpromoting, cytoprotective, and lubricating properties in cartilage metabolism. Biochem Biophys Res Commun 254: 535-541.

Fraser JR, Kimpton WG, Pierscionek BK, Cahill RN (1993) The kinetics of hyaluronan in normal and acutely inflamed synovial joints: observations with experimental arthritis in sheep. Semin Arthritis Rheum 22: 9-17.

Fraser JR, Laurent TC, Laurent UB (1997) Hyaluronan: its nature, distribution, functions and turnover. J Intern Med 242: 27-33.

Frias G, Caracuel MA, Escudero A, Rumbao J, PerezGujo V, del Carmen Castro M, Font P, Gonzalez J, Collantes E (2004) Assessment of the efficacy of joint lavage versus joint lavage plus corticoids in patients with osteoarthritis of the knee. Curr Med Res Opin 20: 861867.

Furst DE (2004) Anakinra: review of recombinant human interleukin-I receptor antagonist in the treatment of rheumatoid arthritis. Clin Ther 26: 1960-1975.

Ghosh P, Guidolin D (2002) Potential mechanism of action of intra-articular hyaluronan therapy in osteoarthritis: are the effects molecular weight dependent? Semin Arthritis Rheum 32: 10-37.

Haubeck HD, Kock R, Fischer DC, van de Leur E, Hoffmeister K, Greiling H (1995) Transforming growth factor $\beta 1$, a major stimulator of hyaluronan synthesis in human synovial lining cells. Arthritis Rheum 38: 669-677.

Hills BA (2000) Boundary lubrication in vivo. Proc Inst Mech Eng [H] 214: 83-94.

Hills BA, Crawford RW (2003) Normal and prosthetic synovial joints are lubricated by surface-active phospholipid: a hypothesis. J Arthroplasty 18: 499-505.

Jay GD, Britt DE, Cha DJ (2000) Lubricin is a product of megakaryocyte stimulating factor gene expression by human synovial fibroblasts. J Rheumatol 27: 594-600.

Jay GD, Cha DJ (1999) The effect of phospholipase digestion upon the boundary lubricating activity of synovial fluid. J Rheumatol 26: 2454-2457.

Jensen LT, Henriksen JH, Olesen HP, Risteli J, Lorenzen I (1993) Lymphatic clearance of synovial fluid in conscious pigs: the aminoterminal propeptide of type III procollagen. Eur J Clin Invest 23: 778-784.

Kaneyama K, Segami N, Sun W, Sato J, Fujimura K (2005) Analysis of tumor necrosis factor-alpha, interleukin6 , interleukin-1beta, soluble tumor necrosis factor receptors I and II, interleukin-6 soluble receptor, interleukin-1 soluble receptor type II, interleukin-1 receptor antagonist, and protein in the synovial fluid of patients with temporomandibular joint disorders. Oral Surg Oral Med Oral Pathol Oral Radiol Endod 99: 276-284.

Kedem O, Katchalsky A (1958) Thermodynamic analysis of the permeability of biological membranes to non-electrolytes. Biochim Biophys Acta 27: 229-246.

Knight AD, Levick JR (1984) Morphometry of the ultrastructure of the blood-joint barrier in the rabbit knee. Q J Exp Physiol 69: 271-288.

Laurent UB, Fraser JR, Engstrom-Laurent A, Reed RK, Dahl LB, Laurent TC (1992) Catabolism of hyaluronan in the knee joint of the rabbit. Matrix 12: 130-136.

Levick JR (1980a) Absorption of artificial effusions from synovial joints: an experimental study in rabbits. Clin Sci (Lond) 59: 41-48.

Levick JR (1980b) Contributions of the lymphatic and microvascular systems to fluid absorption from the synovial cavity of the rabbit knee. J Physiol 306: 445461.

Levick JR (1981) Permeability of rheumatoid and normal human synovium to specific plasma proteins. Arthritis Rheum 24: 1550-1560.

Levick JR (1987) Flow through interstitium and other fibrous matrices. Q J Exp Physiol 72: 409-437.

Levick JR (1990) In: Methods in Cartilage Research (A. Maroudas and K. E. Kuettner) Academic Press, New York, 352-357. 
Levick JR (1994) An analysis of the interaction between interstitial plasma protein, interstitial flow, and fenestral filtration and its application to synovium. Microvasc Res 47: 90-125.

Levick JR (1998) A method for estimating macromolecular reflection by human synovium, using measurements of intra-articular half-lives. Ann Rheum Dis 57: 339-344.

Levick JR, McDonald JN (1989a) Synovial capillary distribution in relation to altered pressure and permeability in knees of anaesthetized rabbits. J Physiol 419: 477-492.

Levick JR, McDonald JN (1989b) Ultrastructure of transport pathways in stressed synovium of the knee in anaesthetized rabbits. J Physiol 419: 493-508.

Lu Y, Levick JR, Wang W (2005) The mechanism of synovial fluid retention in pressurized joint cavities. Microcirculation 12: 581-595.

Mahlbacher V, Sewing A, Elsasser HP, Kern HF (1992) Hyaluronan is a secretory product of human pancreatic adenocarcinoma cells. Eur J Cell Biol 58: 28-34.

Maroudas A (1970) Distribution and diffusion of solutes in articular cartilage. Biophys J 10: 365-379.

Mason RM, Kimura JH, Hascall VC (1982) Biosynthesis of hyaluronic acid in cultures of chondrocytes from the swarm rat chondrosarcoma. J Biol Chem 257: 2236-2245.

Mathies B (2006) Effects of Viscoseal, a synovial fluid substitute, on recovery after arthroscopic partial meniscectomy and joint lavage. Knee Surg Sports Traumatol Arthrosc 14: 32-39.

Mazzucco D, Scott R, Spector M (2004) Composition of joint fluid in patients undergoing total knee replacement and revision arthroplasty: correlation with flow properties. Biomaterials 25: 4433-4445.

McDonald JN, Levick JR (1988) Morphology of surface synoviocytes in situ at normal and raised joint pressure, studied by scanning electron microscopy. Ann Rheum Dis 47: 232-240.

McDonald JN, Levick JR (1992) Evidence for simultaneous bidirectional fluid flux across synovial lining in knee joints of anaesthetized rabbits. Exp Physiol 77: 513-515.

McDonald JN, Levick JR (1993) Effect of extravascular plasma protein on pressure-flow relations across synovium in anaesthetized rabbits. J Physiol 465: 539-559.

Momberger TS, Levick JR, Mason RM (2005) Hyaluronan secretion by synoviocytes is mechanosensitive. Matrix Biol 24: 510-519.

Moos V, Fickert S, Muller B, Weber U, Sieper J (1999) Immunohistological analysis of cytokine expression in human osteoarthritic and healthy cartilage. J Rheumatol 26: $870-879$.

Moreland LW (2003) Intra-articular hyaluronan (hyaluronic acid) and hylans for the treatment of osteoarthritis: mechanisms of action. Arthritis Res Ther 5: 54-67.

Moreland LW (2004) Drugs that block tumour necrosis factor: experience in patients with rheumatoid arthritis. Pharmacoeconomics 22: 39-53.
Nugent GE, Aneloski NA, Schmidt TA, Schumacher BL, Voegtline MS, Sah RL (2006a) Dynamic shear stimulation of bovine cartilage biosynthesis of proteoglycan 4. Arthritis Rheum 54: 1888-1896.

Nugent GE, Schmidt TA, Schumacher BL, Voegtline MS, Bae WC, Jadin KD, Sah RL (2006b) Static and dynamic compression regulate cartilage metabolism of proteoglycan 4 (PRG4). Biorheology 43: 191-200.

Ogston AG, Preston BN, Wells JD (1973) On the transport of compact particles through solutions of chainpolymers. Proc Roy Soc Lond A 333: 297-316.

Ogston AG, Stanier JE (1953) The physiological function of hyaluronic acid in synovial fluid: viscous, elastic and lubricant properties. J Physiol 119: 244-252.

Okazaki R, Sakai A, Uezono Y, Ootsuyama A, Kunugita N, Nakamura T, Norimura T (2001) Sequential changes in transforming growth factor (TGF)-beta1 concentration in synovial fluid and mRNA expression of TGF-beta1 receptors in chondrocytes after immobilization of rabbit knees. J Bone Miner Metab 19: 228-235.

Patlak CS, Goldstein DA, Hoffman JF (1963) The flow of solute and solvent across a two-membrane system. J Theor Biol 5: 426-442.

Plaas A, Chekerov I, Zheng Y, Schmidt T, Sah R, Carter J, Sandy J (2006) Disulfide-bonded multimers of lubricin (LGP-1, PRG4) glycovariants in cartilage, synovium and synovial fluid. Trans Orthop Res Soc 52: 1422.

Poli A, Mason RM, Levick JR (2004) Effects of ArgGly-Asp sequence peptide and hyperosmolarity on the permeability of interstitial matrix and fenestrated endothelium in joints. Microcirculation 11: 463-476.

Price FM, Levick JR, Mason RM (1996) Glycosaminoglycan concentration in synovium and other tissues of rabbit knee in relation to synovial hydraulic resistance. J Physiol (Lond) 495: 803-820.

Price FM, Mason RM, Levick JR (1995) Radial organization of interstitial exchange pathway and influence of collagen in synovium. Biophys J 69: 1429-1439.

Rabinowitz JL, Gregg JR, Nixon JE (1984) Lipid composition of the tissues of human knee joints. II. Synovial fluid in trauma. Clin Orthop Rel Res 190: 292298.

Revell PA (1989) Synovial lining cells. Rheumatol Int 9: 49-51.

Rittig M, Tittor F, Lutjen-Drecoll E, Mollenhauer J, Rauterberg J (1992) Immunohistochemical study of extracellular material in the aged human synovial membrane. Mech Ageing Dev 64: 219-234.

Ropes MW, Rossmeisl EC, Bauer W (1940) The origin and nature of normal human synovial fluid. J Clin Invest 19: 795-799.

Sabaratnam S, Arunan V, Coleman PJ, Mason RM, Levick JR (2005) Size selectivity of hyaluronan molecular sieving by extracellular matrix in rabbit synovial joints. $\mathrm{J}$ Physiol 567: 569-581.

Sabaratnam S, Mason RM, Levick JR (2004) Filtration rate dependence of hyaluronan reflection by joint-to-lymph barrier: evidence for concentration polarisation. J Physiol 557: 909-922. 
Sakamoto T, Mizono S, Miyazaki K, Yamaguchi T, Toyoshima H, Namiki O (1984) Biological fate of sodium hyaluronate (SPH): Studies on the distribution, metabolism, and excretion of ${ }^{14} \mathrm{C}-\mathrm{SPH}$ in rabbits after intraarticular administration. Pharmacometrics 28: 375-387.

Schalkwijk J, Joosten LAB, van den Berg WB, van Wyk JJ, van de Putte LBA (1989) Insulin-like growth factor stimulation of chondrocyte proteoglycan synthesis by human synovial fluid. Arthritis Rheum 32: 66-71.

Schmid T, Lindley K, Su J, Soloveychik V, Block J, Kuettner K, Schumacher B (2001a) Superficial zone protein (SZP) is an abundant glycoprotein in human synovial fluid and serum. Trans Orthop Res Soc 26: 82.

Schmid T, Soloveychik V, Kuettner K, Schumacher B (2001b) Superficial zone protein (SZP) from human cartilage has lubrication activity. Trans Orthop Res Soc 26: 178 .

Schmidt TA, Gastelum NS, Nguyen QT, Schumacher BL, Sah RL (2007) Boundary lubrication of articular cartilage: role of synovial fluid constituents. Arthritis Rheum In Press.

Schmidt TA, Schumacher BL, Han EH, Klein TJ, Voegtline MS, Sah RL (2005) In: Physical Regulation of Skeletal Repair (R. K. Aaron and M. E. Bolander) American Academy of Orthopaedic Surgeons, Chicago, 151-162.

Schumacher BL, Block JA, Schmid TM, Aydelotte MB, Kuettner KE (1994) A novel proteoglycan synthesized and secreted by chondrocytes of the superficial zone of articular cartilage. Arch Biochem Biophys 311: 144-152.

Schumacher BL, Hughes CE, Kuettner KE, Caterson B, Aydelotte MB (1999) Immunodetection and partial cDNA sequence of the proteoglycan, superficial zone protein, synthesized by cells lining synovial joints. J Orthop Res 17: 110-120.

Schumacher BL, Schmidt TA, Voegtline MS, Chen AC, Sah RL (2005) Proteoglycan 4 (PRG4) synthesis and immunolocalization in bovine meniscus. J Orthop Res 23: 562-568.

Schwarz IM, Hills BA (1996) Synovial surfactant: lamellar bodies in type B synoviocytes and proteolipid in synovial fluid and the articular lining. Br J Rheumatol 35: 821-827.

Schwarz IM, Hills BA (1998) Surface-active phospholipids as the lubricating component of lubricin. Br J Rheumatol 37: 21-26.

Scott D, Coleman PJ, Mason RM, Levick JR (1997) Glycosaminoglycan depletion greatly raises the hydraulic permeability of rabbit joint synovial lining. Exp Physiol 82: 603-606.

Scott D, Coleman PJ, Mason RM, Levick JR (2000) Interaction of intraarticular hyaluronan and albumin in the attenuation of fluid drainage from joints. Arthritis Rheum 43: 1175-1182.

Scott D, Levick JR, Miserocchi G (2003) Non-linear dependence of interstitial fluid pressure on joint cavity pressure and implications for interstitial resistance in rabbit knee. Acta Physiol Scand 179: 93-101.

Scott DL, Shipley M, Dawson A, Edwards S, Symmons DP, Woolf AD (1998) The clinical management of rheumatoid arthritis and osteoarthritis: strategies for improving clinical effectiveness. Br J Rheumatol 37: 546554.

Smith MM, Ghosh P (1987) The synthesis of hyaluronic acid by human synovial fibroblasts is influenced by the nature of the hyaluronate in the extracellular environment. Rheumatol Int 7: 113-122.

Sullivan R, Hertel K (1942) The permeability method for determining specific surface of fibers and powders. Adv Colloid Sci 1: 37-80.

Swann DA, Silver FH, Slayter HS, Stafford W, Shore E (1985) The molecular structure and lubricating activity of lubricin isolated from bovine and human synovial fluids. Biochem J 225: 195-201.

Swann DA, Slayter HS, Silver FH (1981) The molecular structure of lubricating glycoprotein-I, the boundary lubricant for articular cartilage. J Biol Chem 256: 5921-5925.

Swann DA, Sotman S, Dixon M, Brooks C (1977) The isolation and partial characterization of the major glycoprotein (LGP-I) from the articular lubricating fraction of synovial fluid. Biochem J 161: 473-485.

Tanaka N, Sakahashi H, Hirose K, Ishima T, Ishii S (2006) Volume of a wash and the other conditions for maximum therapeutic effect of arthroscopic lavage in rheumatoid knees. Clin Rheumatol 25: 65-69.

Tanford C (1961) Physical Chemistry of Macromolecules. John Wiley \& Sons, New York, 321-364.

Tehranzadeh J, Booya F, Root J (2005) Cartilage metabolism in osteoarthritis and the influence of viscosupplementation and steroid: a review. Acta Radiol 46: $288-296$.

Van Obberghen-Schilling E, Roche NS, Flanders KC, Sporn MB, Roberts AB (1988) Transforming growth factor beta 1 positively regulates its own expression in normal and transformed cells. J Biol Chem 263: 7741-7746.

Wallis WJ, Simkin PA, Nelp WB (1987) Protein traffic in human synovial effusions. Arthritis Rheum 30: 57-63.

Watterson JR, Esdaile JM (2000) Viscosupplementation: therapeutic mechanisms and clinical potential in osteoarthritis of the knee. J Am Acad Orthop Surg 8: 277-284.

Wei X, Messner K (1998) Age- and injury-dependent concentrations of transforming growth factor-beta 1 and proteoglycan fragments in rabbit knee joint fluid. Osteoarthritis Cartilage 6: 10-18.

Wilkinson LS, Pitsillides AA, Worrall JG, Edwards JC (1992) Light microscopic characterization of the fibroblastlike synovial intimal cell (synoviocyte). Arthritis Rheum 35: 1179-1184.

Worrall JG, Bayliss MT, Edwards JC (1991) Morphological localization of hyaluronan in normal and diseased synovium. J Rheumatol 18: 1466-1472.

Worrall JG, Wilkinson LS, Bayliss MT, Edwards JC (1994) Zonal distribution of chondroitin-4-sulphate/ dermatan sulphate and chondroitin-6-sulphate in normal and diseased human synovium. Ann Rheum Dis 53: 3538 . 


\section{Discussion with reviewers}

C Flannery: It would be interesting to consider further the proportion of the total PRG4/lubricin in a joint that occurs localized to tissue surfaces (i.e. cartilage).

Authors: This proportion can be estimated as follows. The amount of PRG4 bound to the surface of bovine cartilage is $\sim 0.24-0.59 \mu \mathrm{g} / \mathrm{cm}^{2}$ (Schmidt et al., 2005; Nugent et al., 2006). Using parameter values from the present manuscript, a joint with $140 \mathrm{~cm}^{2}$ cartilage surface area (Eckstein et al., 2001) would have a total of $~ 34-83 \mu \mathrm{g}$ bound PRG4. In synovial fluid, the PRG4 concentration is $450 \mu \mathrm{g} / \mathrm{ml}$ (Schmid et al., 2001). Assuming a synovial fluid volume of $1.1 \mathrm{ml}$ (Ropes et al., 1940) yields a total of $\sim 500 \mu \mathrm{g}$ PRG4 in synovial fluid. From these estimates, the proportion of total PRG4 that is bound to the articular cartilage surface would be $\sim 7-17 \%$.

C Flannery: It would be interesting to consider further whether/how this parameter is affected by relative changes in the lubricant composition of the synovial fluid compartment.

Authors: The proportion of PRG4 that is bound may be affected as suggested. The binding of synovial fluid PRG4 to cartilage surfaces occurs in a dose-dependent manner (Swann et al., 1981), and repletion of PRG4 that has been removed from the surface of cartilage is dependent upon the structure of the PRG4 protein (Jones et al., 2006; Nugent et al., 2006).

C Flannery: Are there any alterations to the levels of such boundary-associated molecules which could be predicted for the example cases of joint lavage and HA injection?

Authors: In the case of joint lavage, where the synovial fluid concentration of lubricants is initially brought to $\sim$ zero, PRG4 may be expected to be desorbed or released due to chemical or mechanical factors. The significance of this depletion may depend upon the rate at which it occurs. Rapid depletion may be detrimental to joint lubrication, while slow depletion may be compensated by de novo PRG4 secretion. A similar hypothesis may apply for HA after joint lavage, with differing kinetics. In the case of HA injection, where the HA concentration is transiently increased, HA binding may be expected to increase, possibly in a saturable manner.

\section{Additional References}

Eckstein F, Winzheimer M, Hohe J, Englmeier KH, Reiser M (2001) Interindividual variability and correlation among morphological parameters of knee joint cartilage plates: analysis with three-dimensional MR imaging. Osteoarthritis Cartilage 9: 101-111.

Jones AR, Gleghorn JP, Hughes CE, Fitz LJ, Zollner R, Wainwright SD, Caterson B, Morris EA, Bonassar LJ, Flannery CR (2007) Binding and localization of recombinant lubricin to articular cartilage surfaces. J Orthop Res 25: 283-292.

Nugent GE, Chan AH, Schumacher BL, Sah RL (2006) PRG4 exchange between articular cartilage surface and synovial fluid. Trans Orthop Res Soc 52: 1479.

Ropes MW, Rossmeisl EC, Bauer W (1940) The origin and nature of normal human synovial fluid. J Clin Invest 19: $795-799$.

Schmid T, Lindley K, Su J, Soloveychik V, Block J, Kuettner K, Schumacher B (2001) Superficial zone protein (SZP) is an abundant glycoprotein in human synovial fluid and serum. Trans Orthop Res Soc 26: 82.

Schmidt TA, Schumacher BL, Nugent GE, Gastelum NS, Sah RL (2005) PRG4 contributes to a "sacrificial layer" mechanism of boundary lubrication of articular cartilage. Trans Orthop Res Soc 30: 900.

Swann DA, Hendren RB, Radin EL, Sotman SL, Duda EA (1981) The lubricating activity of synovial fluid glycoproteins. Arthritis Rheum 24: 22-30. 